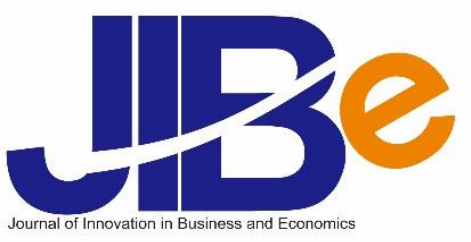

\title{
Community Participation in Village Development from Islamic Economic Perspectives
}

\author{
Nisa Mutiara ${ }^{1}$, Djoko Mursinto $^{2}$, Zainuddin Maliki $^{3}$ \\ Faculty of Economics, Universitas Islam Kadiri, \\ Kediri, Indonesia ${ }^{1}$ \\ Faculty of Economic and Business, Universitas Airlangga, \\ Surabaya, Indonesia ${ }^{2}$ \\ Postgraduate School, Universitas Muhammadiyah Surabaya, \\ Surabaya, Indonesia ${ }^{3}$
}

\begin{abstract}
The implementation of the Law No. 6 of 2014 and the Village Fund in 2015 was able to encourage community participation in the entire development process starting from planning, implementation, supervision and utilization. This study aimes to analyze community participation in Megaluh Village by using an Islamic perspective. This study applied a case study approach to community participation and a literature review to determine community participation after the implementation of the Village Law from an Islamic economic perspective which are called maqhasid sharia. In general, Megaluh villages have shown active community participation in village development, but they still need to carry out long-term planning to ensure prosperity and this has not been observed during the study.
\end{abstract}

Keywords: Community participation; Law No. 6 of 2014; Islamic economic perspective; maqashid sharia

\section{Introduction}

Village has existed before the Unitary State of the Republic of Indonesia was formed. These areas have original settings. Therefore, village can be considered a special area. The Republic of Indonesia respects the status of these special regions. All state regulations regarding these areas will be related to the rights of origin of the area. Therefore, their existence must be recognized and guaranteed for their survival in the Unitary State of the Republic of Indonesia. On the other hand, urbanization has become a familiar phenomenon. Extraordinarily, in 2010 the urban population had reached $49.79 \%$ of the total population in Indonesia. This means that there are 118 million people living in urban areas, and another 50.21\% living in rural areas (Badan Pusat Statistik, 2010). This phenomenon is not only due to the assurance of prosperity offered by the city, but also other factors that drive urbanization, namely economic backwardness, lack of facilities and infrastructure (i.e. inadequate transportation and education facilities), and limited employment in the rural areas (Muhi, 2011). Previous research by Green (2005), Baglioni (2015), Rasila (2013), and Permana (2013) revealed an increasing community involvement in development and the community had held important positions in policy making, namely: linked to the government.

Nonetheless, the communication gap between the government and the community can hamper the development as it requires identification of challenges and implementation of strategies and a sense of shared responsibility from the government and the community for the success of the development. The constraints on the ineffectiveness of village community participation in development are conveyed by Pramanik (2012), Kristanti (2016), Waheduzzaman (2010). It is argued that the village government lacks of awareness on the importance of the value of community participation. Therefore, it is necessary that the government invite the community to be more active in the development. Chado and Johar (2016) stated that community participation is a process for involving the citizens in decision-making in developing countries. Although there is an axiomatic desire of the community to participate, the motivation becomes insignificant. Therefore it is necessary to improve the program of participation in the planning and management of social economic activities in a region.

The government systems before reformation era are centralized governance which means that planning and implementation of development applied a top-down system. Meanwhile, in the reformation

${ }^{1}$ E-mail: nisa.kediri888@gmail.com

${ }^{2}$ E-mail: mursinto@gmail.com

${ }^{3}$ E-mail: maliki@gmail.com 
era, which was marked by the monetary crisis in 1998 , the bottom up system was ran by the government. In fact, not all regional governments and village governments are able to support their own administration and their own financial development. Therefore, the central government provides financial assistance through transfer of funds from the central government to local governments and continues to village governments (multilevel). The central government authorizes local governments and village governments to regulate their own finances, for government administration and for development or called fiscal decentralization. So that there is enough funds to carry out government activities and development. This is regulated in Law No, 32 of 2014 concerning Regional Government Article 1 paragraph 7 and Law No. 33 of 2014 concerning Financial Balance between Central Government and Regional Government.

Therefore the government regulates village autonomy through Law No. 72 of 2005 . Along with the enactment of government regulations, the regional government transferred funds as part of the regional balance fund known as Village Fund Allocation (ADD), which was sourced from the Regional Budget (APBD). Yet, the practical government regulation No. 72 of 2005 has not involved village community participation optimally yet. It should involve the community in all aspects of development and not only at the planning and utilization stage. Therefore, the enactment of Law No. 6 of 2014 provide opportunities for rural communities to participate in all stages of village development from planning, implementation, supervision to utilization so that village welfare can be realized and sanctions can be imposed on local governments or village governments who do not implement it.

Creating a prosperous village community or in Islam called falah is a common goal of Law No. 6 of 2014 (Ridlwan, 2015; Supriadi, 2015). Mulyono (2014) Using the Village Welfare Society (VWS) approach which emphasizes expenditure, Mulyono found that the implementation of village funds was not optimal because of uneven human resource factors. In reverse, this finding is directly proportional to research in Bangladesh which revealed that village development involving third parties would be able to increase effectiveness in poverty alleviation. This is very possible because third parties involved in village development have better human resources (Galasso \& Ravallion, 2005).

However, the concept of prosperity according to Islam is a life test, as stated in Quran Surah AlAnfal (28:8). Therefore, it is very important to maintain the use of the Village Fund based on the maqashid shariafor the benefit of the people and the realization of real prosperity or falah. Welfare, in the concept of Islam, is not only seen from the material side but also a good spiritual life. Islam has put maqashid syaria as an important point in shariawhich highlights the prosperity of all humanity as the main goal. Imam AlGhazali has set a goal of sharia(maqashid shari'a) which includes maintaining and keeping religion (hifzad-deen), soul (hifzan-nafs), mind (hifzal-aql), descendant (hifz an-nasl), and assets (hifzalmaal). Of all these five things, the most important one is maslahah, the consistent preservation of maqhashid shari'a.

Megaluh Village is located in Jombang Regency which in its development upholds the values contained in Islamic philosophy namely Baldatun Thoyyibatun Warobbun Ghoffur. However, according to the BKKBN classification, in 2013, it is found that 253 Leader of Family $(K K)$ or $26 \%$ of Megaluh residents were classified as under the line of poverty. This becomes a big challenge for the governments and communities of Megaluh village. This research was aimed at analyzing community participation after the enactment of Law No. 6 of 2014 accompanied by the disbursement of Village Funds starting in 2015 in realizing health from the perspective of Islamic Economics.

Although the current Government system adheres to a bottom-up system, Law No. 25 of 2004 concerning the national development planning system and regional development planning must be in line with national development. Regional autonomy is regulated in Law No. 32 of 2004 as amended in Law No. 23 of 2014. While village autonomy was initially regulated through Law No. 72 of 2005, due to ineffective implementation of village autonomy, it was changed to Law No. 6 of 2014 concerning Villages. Article 79 paragraph 1 of Law No, 6 of 2014 states that the Village Government, in preparing village development planning, must fulfill its authority by referring to District development planning or top-down and regulated by Regent Regulation, This shows that the government wants harmonious development between the central government, local governments and village governments.

The village fund transfers in 2017, consisted of Village Fund Allocation, currently have reached an average of Rp. 1 billion per village. Therefore, it is expected that all the villagers and the village government have a freedom to plan and manage the budget to improve village prosperity. The big amount of Village Fund becomes a major challenge for the village government to be able to increase the participation of rural communities, particularly the Muslim community, in terms of planning, implementation, monitoring and utilization of rural infrastructure to meet the right form of welfare.

Village development attempts to improve the prosperity of rural communities and the quality of human life. In addition, village development controls of adversity through the basic needs or primary needs, 
development of village facilities and infrastructure, development of local economic potential, and utilization of natural and sustainable environmental resources. The enactment of Law No 6 of 2014 accompanied by the Village Fund in 2015 has broadly and significantly increased village community's participation in development, starting from planning, execution, supervision and utilization. The amount of village expenditure needs for the development compared to the income received requires the participation of the village community to choose and sort it so that it is able to carry out development in accordance with the priorities of the community's needs. The improvement of the village must also be supported by the existence of village officials and the Village Council (BPD) which functions to establish village regulations accompanied by the village head. The village head as the chief of the government at the village level in carrying out his duties and obligations, has a responsibility to account to the community through the BPD and submit a report on the implementation of his duties and stipulated with the BPD.

Village institutions are community organizations or associations, parties, groups in the village that come from the executive, legislative and community elements involved in the preparation, implementation and supervision of the Regional Budget. This institution includes: 1) village government;2) BPD; 3) village community institutions (LPMD); 4) community leaders, and stakeholders. As a practice of democracy, village which is formed as a legislative body, functions to make village regulations, accommodate and communicate the community aspirations and supervise the administration of village government, BPD members are elected from and by villagers, while the BPD leadership is chosen by the BPD members themselves. The BPD together with the village head establishes village regulations, decides village income and expenditure budgets, defines and forms other village institutions according to village needs, constructs village business entities. The implementation of village regulations is determined by the village head's decision. Village Community Institution consists of LPMD, Family Health Empowerment (PKK), Yout Community (Karang Taruna), Farmer Union (Gapoktan), and others.

\section{Literature Review Rural Community}

Village is a form and development of the original concept of the Indonesian people, although there are some similarities with villages in India which are nuanced in Hinduism. The life of the village community is tied to indigenous cultural values that have been inherited from generation to generation and through a very long process of adaptation from intensive interactions with changes in the community's biophysical environment. Local wisdom is one aspect of community characteristics, which is formed through a process of adaptation that is beneficial to people's lives, so that the values contained therein should be understood as the basis for agricultural and rural development (Sumardjo, 2010).

Presently, the conditions of rural communities are diverse, ranging from the behavior of moving farms, permanent farming, industrial villages, and villages with the dominant livelihoods of the service sector to villages which with modern facilities can be found in the territory of Indonesia. The village contains a number of local wisdom which, if observed, the values contained in it can be a force to adapt to the environment in which the community lives. Local wisdom can be observed from the rules, norms, rules of morality, language, institutions, names and titles, and technology used (house construction, house layout, irrigation techniques, soil processing techniques and equipment, techniques for constructing roads/bridges, boat techniques and so on). If the values contained in these aspects are considered in the development of technology in this modern era, even though they use different materials, environmental compatibility and adaptability appear to remain high. Weber (1947) in Maliki (2015) dan Lubis (2015) stated that there are mutual influences between religion and society.

\section{Participation}

Community participation has theoretically been accommodated in the development planning procedures which have been adopted so far. If there is lack participation of community, it might be caused by the process of raising community participation has not been properly understood by all parties involved. Participation can be further enhanced through a more acceptable and motivating method application so that people will be able to help themselves in overcoming the problems they face (Adisasmita, 2013). Bryan and White (1989), describes the notion of deeper participation in the field of development administration as participation by the community or project beneficiaries in the design and implementation of the project. The meaning of this participation implies an attitude of openness to perceptions and feelings of others, deep attention to the differences and changes that will result in a project in relation to people's lives, as well as awareness of the contributions that other parties can make to an activity. In the 1950s and 1960s, participation was defined as voting, party membership, activities in voluntary associations, protest movements and so on. This political participation can be divided into 
two. First, horizontal participation that involves the community collectively to influence policy decisions. Second, vertical participation occurs when community members develop certain relationships with elite groups and officials that are beneficial to both parties.

Participation starts to be associated to the administrative processes by including participation activities in the implementation process so that individuals and groups can pursue conflicting interests and compete for scarce resources. The study conducted by Uma Lele in 1975 in Bryan and White (1989), showed that participation in planning and implementing programs can develop the independence needed by members of rural communities for the accelerated development. In addition, the expansion of the concept of participation includes not only the planning and implementation process but also participation in receiving benefits. The argument submitted is the possibility of the community not benefiting from the contributions it gives. Bryant and White (1987) also reminded that the concept of participation was not narrowed only to the aspect of mere benefits because it would change the general understanding of participation. The aspect of receiving benefits is a complement to the scope of the planning and implementation process so as to bring greater benefits to the community. In addition to participation in planning, implementing and receiving benefits, Griesgraber and Gunter (1996), added aspects of evaluation by interpreting participation as a mechanism involving the community in a program starting from the identification stage to the implementation and evaluation stages. Thus the concept of participation becomes so wide ranging from the aspects of planning, implementation, and evaluation to the acceptance of the benefits. According to Griesgraber and Gunter (1996) participation can be interpreted as the mechanism for managing plans or programs, beginning with all the way through implementation and evaluation.

\section{Human as The Development Actors in Islamic Perspectives}

Every development would be impossible without the actors. The actors of the development are humans. Development commonly sees humans in physical aspects only and not paying attention on the spiritual aspects (Salleh, 2003). According to Islam, humans are individuals that are a combination of body and spirit. Therefore, humans as development actors, must maintain their status as servants and caliphs of Allah SWT. In relation with Allah SWT (hablum-minallah), humans are the servants of Allah SWT and in human relations with fellow human beings and natural resources (hablum-minannas), humans are caliphs appointed by Allah SWT. As stated in Quran Surah Al-A'raf (7:172). Economics is the study of human behavior related to achieving goals with the use of limited facilities that have alternative uses. Economics is a study that studies the way humans achieve prosperity and distribute it. The next question is how goods and services will be distributed. The method that people take to answer this question is to determine the economic system that is applied. Although there are similarities in the emergence of economic activities caused by the needs and desires of humans, various forms of economic systems and practices emerge from many countries in the world. This is caused by various methods that humans use to meet their needs and methods for distributing these needs based on different philosophies (Mannan, 1997).

\section{People's Role (N) and Government (G) According to Ibnu Khaldun in Dynamic Models}

Ibn Khaldun was a politician who deeply understood the world of Islamic politics in the fourteenth century. Seeing the collapse and weakness of the Islamic world in general at the time, and observing for themselves the decline of Arab-Islamic culture in Andalusia under pressure from Spanish forces, he argued that everything would be destroyed. Some scholars even refer to Ibn Khaldun as the actual Father of Economics or the father of modern social science and claim that ideas initiated by Ibn Khaldun influenced some thinkers such as Adam Smith or David Ricardo, and later by Karl Marx or John Maynard Keynes, centuries later.The history of Muslims clearly illustrates the interplay between people $(\mathrm{N})$, sharia $(\mathrm{S})$, government $(\mathrm{G})$, welfare or economy $(\mathrm{W})$, justice (j) and development $(\mathrm{g})$ in terms of the ups and downs of civilization. This was delivered by Ibn Khaldun in 1332-1406 or known as Ibn Khaldun Dynamic Model as represented in Figure 1 below. 


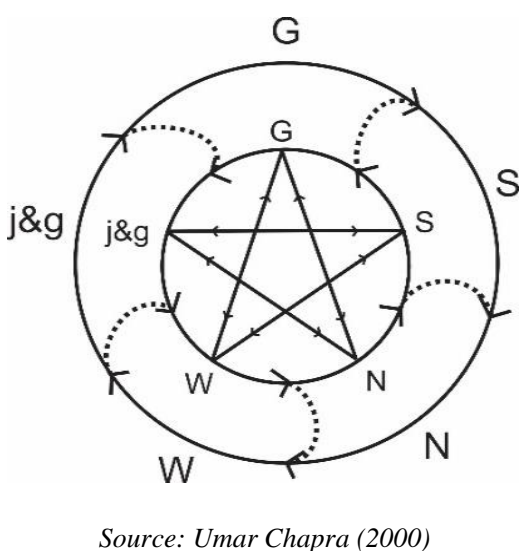

Figure 1. Ibn Khaldun's dynamics model

\section{Maqashid Al-Sharia As Strategy to Realize Welfare}

Imam Al-Ghazali in his book Ihya 'Ulumuddin (505 Hijriah/1111 AD) stated that in maqashid alsyari epistomologically consisted of two words, namely maqashid and sharia. Maqashid is the plural form of maqshud which means intention, or purpose. Sharia means the road to water, or it can be said to go to the source of life (Fauzia, 2014). The aim of Islam is to increase the prosperity of all humanity, which lies in maintaining and preserving religion (Hifz Ad-Diin), soul (Hifz An-Nafs), descent (Hifz An-Nasl), reason (Hifz Al-Aql), and wealth (Hifz Al-Maal). Of all the fifth guards, the most important thing is maslahah, the preservation of maqhashid maslahah shari'ah consistently. The concept of maslahah as a public interest and the basis of public expenditure was conveyed in Al-Mustasfa by Imam Al-Ghazali in the 5th century Hijri. This work shows the focus of Imam Al-Ghazali on the protection of the public interest. Therefore this concept is related to improving social welfare and material society. And based on the definition of maslahah, the state's obligations become broad and flexible. Therefore public expenditure has a very broad scope that is determined in maslahah (Azmi, 2009).

\section{Research Method}

The research method applied in this present study is a case study. Case study research is one of the studies that uses a non-mainstream approach that is included in the interpretive paradigm (Basuki, 2016). Case study research is very suitable as a research strategy whose research question is related to 'how' or 'why', and in which researchers have little opportunity to control the events that will be investigated, and when the focus of the research lies in contemporary (present) phenomena in real life contexts. Case study research has three characteristics, namely: 1) related to the question "how"; 2) related to the question "why"; and 3) researchers do not have control over the phenomenon and focus on contemporary things (Yin, 2015). According to Robert K. Yin (2015), based on the research focus set by the author, the most suitable research design for the present study is type 1, a single case design with a single unit of analysis, namely the case of community participation with the unit of analysis of Desa Megaluh. The data were obtained through in-depth interviews with 15 informants, consisting of five key informants and 10 supporting informants, consisting of the government and the Megaluh Village community.

The validity of the data is completed by checking the data that has been obtained through several sources as called as Triangulation Method. According to Patton in Moleong (2006) triangulation from sources means comparing sources. The validity of this model is done by cross checking the information obtained from different sources. In this study, researchers conducted repeated interviews with informants. Interviews are conducted several times in a row with the same basic questions. And when data from several sources have similarities or constancy, the data is said to be accurate or valid. As for achieving the validity, several steps are taken, among others; 1) comparing the observation data with the data from interviews; 2) comparing what people are saying in public to what is said in private; 3) comparing the perspective of the interviews from different sides, for example, ordinary people in the village, on the same question; and 4) comparing the result of interviews with relevant documents. To compile a role model, researchers used literature studies combined with reflective thinking. The selection of literature study methods in order to ensure sharialegal truth about Islamic participation models can only be employed with literature review as the sharialaw is contained in Islamic literature. It cannot be employed with other qualitative methods or quantitative methods. 


\section{Result and Discussion}

Law No. 6 of 2014 has given opportunities for village community participation, ranging from planning, execution, monitoring, supervision, reporting, and utilization of the whole community by involving villagers. Concerning the development of Megaluh Village after the implementation of Law No. 6 of 2014 and after the existence of the Village Fund in 2015, on Thursday 3 November 2016 Arifin (Head of Megaluh Village) said:

"With this Village Fund, Megaluh village community is more active in planning the village development and implementing any village activities in an eagerly manner, because the implementation is done by Megaluh village people so there is a turnover of money in the village of Megaluh. The Village Fund is, at the same time, as the wishes of the Village Heads at the meeting of all Village Heads in Indonesia in Jakarta in 2014 which was simultaneously in line the implementation of Law no. 6 Year 2014 on Village".

In case of the form of community participation in Megaluh Village in terms of development planning, Eko Junaidy, S.PdI. (Development Planning Staff of Megaluh Village) said:

"People were present at the RT meeting to convey their aspirations, they could also be represented by the $R T$ head, and then the results of the Musdus were taken to the Musrenbangdes. They are the development target, if at the time of the Musrenbangdes there is no agreement on village development priorities, then it has been agreed upon for the Drafting Team. Because there are so many recommendations, we consider priorities and determine the scale of justice or equality of development. The regulatory team consisted of 9 people, from elements of the village government, namely village officials, community leaders, religious leaders, youth leaders, female leaders, figures from Poor Households (RTM)".

Villagers of Megaluh are involved in development not only in planning and utilization but also involved in the implementation of village development through the Implementing Team of Activities (TPK) established by LPMD and village development monitoring. Information added by M. Abdul Qodir, SE, Chairman of Youth Organization cadets and TPK members:

"Yes, they were involved, in terms of stewardship of the implementation of village development which was represented by the LPMD which later formed TPK. For the craftsmen and transporters of goods we involved all parties, namely communities in Megaluh Village. If there is no artisan in a hamlet, like in Hamlet Kedungurip, we took it from another hamlet, the most important thing is that they are still residents of Megaluh Village ".

Regarding the supervision of Megaluh village development, Ir. Kusno (Head of BPD Desa Megaluh) said:

"Alhamdulillah (thanks to Allah), during this special event such as abuse of authority or violation, there is no development master plan. Even if there is, the development process can be recognized so that it can still be adjusted. Here the TPK acts as a supervisor, if there is such an event, then we report it to the BPD, the problem is over. And our position is all the same, TPK does not have a gap, our communication always continues. So every small problem can be handled quickly, thus the community will only know the truth".

Regarding the use of development results, M. Zuhri S.Pdi (community leaders):

"Most villagers show their concern for the results of development, only a few people do not care. Even though it has been determined by the village government, the community as users of development results must also be more caring".

After the enactment of Village Law No. 6 of 2014 and after the initiation of Village Fund in 2015 the development of Megaluh Village is also reflected in the village expenditure in the APBDes Megaluh Village. The Table 1 represents the results of local wisdom in realizing Islamic prosperity that has been achieved by the Megaluh Village community through village expenditure arrangements. The use of Megaluh Village Fund based on the Megaluh Village Budget after the enactment of Law No. 6 of 2014 and the Village Fund in 2015.

Table 1. Islamic community wealth in Megaluh Village (in thousands)

\begin{tabular}{lccc}
\hline \multicolumn{1}{c}{ Description } & $\mathbf{2 0 1 5}$ & $\mathbf{2 0 1 6}$ & $\mathbf{2 0 1 7}$ \\
\hline Maintaining Religion (Hifz Ad-Diin) & 46,500 & 35,798 & 22,750 \\
Guarding of the soul (Hifz An-Nafz) & 12,330 & 45,175 & 405,685 \\
Guarding of Intellect (Hifz Al-Aql) & - & 10,800 & 12,600 \\
Guarding of property (Hifz Al-Maal) & 608,640 & 658,607 & 691,764 \\
Child Guard (Hifz An-Nasl) & 22,200 & 201,176 & 119,013 \\
Total Expenditure & 689,670 & $1,186,873$ & 1.270 .813 \\
\hline Source:
\end{tabular}

Source: Income budget and expenditure of Megaluh Village 2015-2017

Based on the results of the above research, it was revealed that Megaluh Village community carried out their own infrastructure development through the formation of TPK by LPMD, where the 
experts, construction workers (manual laborers), and purchasing building materials in building material stores in Megaluh Village. In this way, job opportunities can be opened. This can help increasing the income and circulation of money in Megaluh Village and the education of rural communities. Megaluh Village funds have been used to maintain religion activities (HifzAd-Diin), mind (HifzAl-Aql), soul (Hifz An-Nafs), descent (Hifz An-Nasl) and wealth (Hifz Al-Maal). All materials needed have been fulfilled and spirituality has been increased (material fulfillment and spiritual uplift) according to the needs of public interest through a deliberation. Conserving the five things of the Maqashid Shariaconsistently is maslahah. Islamic participation models with the name Incredible Participation can be seen in Figure 2.

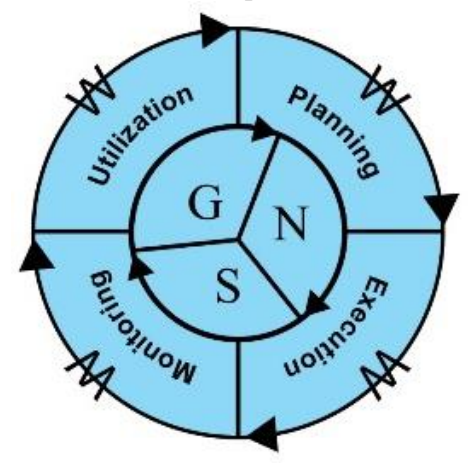

Figure 2. The incredible participation

The concept of maslahah as a public interest and the basis of public expenditure is defined by Imam Al-Ghazali in the book Al-Mustasfa $(500 \mathrm{H})$. Maslahah keeps the object which includes five things: guarding religion, life, mind, lineage, and wealth. Any attempt to ensure the security of these five matters is maslahah. This shows Imam Al-Ghazali's focus on protecting public interests. Therefore this concept is related to improving social and material welfare of the community (W). By definition of maslahah, the state's obligations are broad and flexible. Government $(\mathrm{G})$, people $(\mathrm{N})$ and sharia $(\mathrm{S})$ have the same big role in the entire development process; from planning, implementation, monitoring and utilization to realize welfare or falah (W). Exceptional participation is the participation of Islam in development. Extraordinary Participation shows the role of people, government and sharia rules, through the door of ijtihad by ulama (Islamic scholars) in accompanying development, together in development to realize prosperity (falah). As stated by the Qur'an Surat Al-Hud (11:61) humans were created to worship Allah SWT and to create prosperity.

The Indonesian government, which gives full authority to villages to manage its development, is an extraordinary step in supporting maqashid sharia, the decentralization policy implemented can make the community the main actor of development. This is consistent with the research conducted by Dariah, Salleh and Shafiai (2006). The results of this study provide a new approach that is proposed in a more comprehensive conceptual framework that includes human development efforts and system development as a medium for implementing economic, social, educational, and development mechanisms from an Islamic perspective. Where according to Islam, the spiritual component forms a physical component. And this research proposes an Extraordinary Participation Model as Islamic participation in rural development in Indonesia. Humans as development actors have an important role in realizing prosperity and the spiritual component has a role to form a physical component for sustainable development in order to achieve prosperity. Management authority given to third parties in this regard is the LPD, as has been done in Bangladesh, also provides empirical evidence that development objects are more targeted and reduce shocks in the community (Galasso \& Ravallion, 2005)

In general, Megaluh villages have shown active community participation in village development, but they still need to carry out long-term planning to ensure prosperity and this has not been observed during the study. This finding also believes that although Megaluh Village has implemented five Maqhashid Shariah variables, however, as Mulyono's findings (2014) which conducted research with the village social welfare approach, the Maqhashid Shariah approach also shows that the importance of human resources in carrying out sustainable village development planning. These two findings from two different approaches indicate that there is a need to increase human resources in the village so that the goal of achieving prosperity can be achieved. Problems such as the lack of optimal use of village funds, lack of experts and the absence of a remote master plan are real challenges facing villages in Indonesia (Ramly, Wahyuddin, Mursyida, \& Mawardati, 2018). 
Therefore, based on research finding by (Galasso \& Ravallion, 2005) we recommend that the government provide long-term development assistance so that development will be sustainable and not partial. The master plan is tailored to the potential of each village, including technical assistance in the fields of finance, planning and supervision. If these things can be implemented properly in accordance with the theoretical and empirical discussions that we have presented, the concept of the extraordinary development of Islamic Maqashid will have a positive impact on achieving prosperity. Some of study stated that the quality of human resources is an important factor and this is also in line with Ibn Khaldun's dynamical model which certainly does not only emphasize participation but also the quality of participation in synergy with the government (Gylfason, 2001; United Nations Development Programme, 2016).

In the midst of the lack of optimal village funds due to human resources, it is important to note that Participation in village development after the enactment of the Village Law No. 6 of 2014 was driven by village funds in 2015 as the largest source of income in rural development and the efforts of religious leaders to accompany the efforts of ijtihad. Therefore, all efforts towards prosperity in accordance with sharia through the implementation of village development can be carried out by the community itself. In addition to facilitating supervision, it also enables the realization of sustainable development. Empowerment through the implementation of village development by the villagers themselves, supervised by the amar ma'ruf nahi mungkar approach and sustainable development involving youth able to maintain maqashid syari'ah and accelerate the realization of the welfare (falah) of the villagers. Once again, if it is considered not maximal, the involvement of third parties is highly recommended. In simple terms it can be concluded that very high community participation will be less optimal without being based on qualified knowledge and skills.

\section{Conclusions, Suggestion and limitations}

Based on this research, Law No. 6 of 2014 and the disbursement of village funds in 2015 made development viewed from the perspective of Maqhashid Sharia going well, this was also indicated by high community participation in development. However, high participation has not been matched by a measurable and sustainable concept of development because there are indications of the low quality of human resources. Therefore, the central government needs to consider accelerating the improvement of the quality of human resources, for example by cooperating with third parties to carry out comprehensive assistance from planning to supervision.

This research is limited to whether the development in Megaluh Village has fulfilled the basic elements of Maqhashid Sharia and has not seen the extent to which it is effective in general welfare. Therefore, in the next study we suggest to look at the effect of Maqhashid Sharia on increasing welfare in villages that are generally Muslim majority with empirical evidence showing that the Maqhashid Sharia concept is truly feasible to be implemented in order to increase prosperity.

\section{References}

Adisasmita R. (2013). Pembangunan perdesaan pendekatan partisipatif, tipologi, strategi, konsep desa pusat pertumbuhan. Yogyakarta: Graha ilmu

Anggaran pendapatan dan belanja desa (APBDesa) tahun 2014-2017 Pemerintah Desa Megaluh Kecamatan Megaluh Kabupaten Jombang Propinsi Jawa Timur

Attia, Gamal Eldin. (2010). Towards realization of the higher intens of islamic law: maqashid al-shari' ah a functional approach. Selangor: Vinlin Press Sdn. Bhd

Azmi, Sabaruddin. (2009). Islamic economics. New Delhi: Goodword Books

Badan Pusat Statistik. (2010). Jumlah dan Distribusi Penduduk. Accessed June 2018 at https://sp2010.bps.go.id/

Baglioni, Simone. (2015). Multi-level governance, The EU and civil society: a missing link?. Critical Perspectives on International Public Sector Management, 4, 163-182

Basuki \& Sarmanu. (2015). Metode Penelitian kualitatif (teori dan praktek). Surabaya: Fakultas Kedokteran Hewan Universitas Airlangga

Basuki. (2016). Metode penelitian akuntansi dan manajemen berbasis studi kasus. Surabaya: Airlangga University Press.

Bryant, Carolie \& Louise G. White. (1987). Manajemen pembangunan untuk negara berkembang. Penerjemah: Rusyanto L. Simatupang. Jakarta: LP3ES

Chado, Jiman and Johar, F.B. (2016). Public participation efficiency in traditional cities of developing countries: a perspective of urban development in bida, Nigeria. Procedia-Social and Behavioral Sciences, 219, 185-192

Chapra, M. U. (2000). The future of economics, an islamic perpective. United Kingdom: The Islamic 
Foundation

Dariah, Atih Rohaeti, Salleh, M. S., and Shafiai, H.M. (2016). A new approach for sustainable goals in islamic perspective. Procedia-Social and Behavioral Sciences, 219, 159-166

Fauzia, Yunia, Ika., Riyadi, A. K. (2014). Prinsip dasar ekonomi islam: Perspektif maqashid al-syariah. Jakarta: Prenadamedia

Galasso, E., and Ravallion, M. (2005). Decentralized targeting of an antipoverty program. Journal of Public Economics, 89(4), 705-727. https://doi.org/10.1016/j.jpubeco.2003.01.002

Gylfason, T. (2001). Natural resources, education, and economic development. European Economic Review, 45(4-6), 847-859

Green, B.C. (2005). Building sport programs to optimize athlete recruitment, retention and transition: Toward a normative theory of sport development. Journal of Sport Management, 19, 233-253

Griesgraber, J.M. \& B.G. Gunter. (1996). Development: new paradigms and principles for the twenty-first century. East Haven: CT Pluto Press

Kementrian Agama Republik Indonesia. (2018). Al-Qur'an dan terjemahannya

Khaldun, M. B., Abdurrahman, Al-Allamah. (2011). Mukaddimah Ibnu Khaldun. Jakarta: Pustaka AlKautsar

Lubis, Rodwan. (2015). Sosiologi agama: memahami perkembangan agama dalam interaksi sosial. Jakarta: Prenadamedia Group

Maliki, Zainuddin. (2012). Rekonstruksi teori sosial modern. Yogyakarta: Gadjah Mada University Press

Mannan, M.A. (1997). Teori dan praktek ekonomi islam. Yogyakarta: PT. Dana Bhakti Prima Yasa

Mawdudi, A’la, Abdul, S., Chapra, M. U., (1979). Islamic perspectives. London - English: The Islamic Foundation

Moleong Lexy, J.. (2002). Metode penelitian kualitatif. Bandung: PT. Remaja Rosdakarya

Mulyono, S. P. (2014). Sinergitas penyelenggaraan pemerintahan desa pasca pemberlakuan UU No. 6 tentang desa. Masalah-Masalah Hukum, 43(3), 438-444

Muhi, Ali Hanapiah. (2011). Fenomena pembangunan desa. Institut Pemerintahan Dalam Negeri, Jatinangor, Jawa Barat

Kristiani, Djoko Mursinto., Mardiyanta, Antun. (2017). Model development of civil society participation in post implementation of rural development Act No.6, 2014 in Banaran Grogol, District of Sukoharjo. Journal of Economics and Sustainable Development, 8(8), 187-184

Peraturan Bupati Jombang Nomor 21 Tahun 2017 tentang tata cara pengalokasian, penyaluran, penggunaan dan pertanggungjawaban alokasi dana desa Kabupaten Jombang Tahun 2017

Peraturan Bupati Jombang Nomor 22 Tahun 2017 tentang tata cara pengalokasian, penyaluran, penggunaan dan pertanggungjawaban dana desa di Kabupaten Jombang Tahun 2017

Peraturan Bupati Jombang Nomor 23 Tahun 2017 tentang tata cara pengalokasian, penyaluran, penggunaan dan pertanggungjawaban bagian dari hasil pajak daerah dan restribusi daerah kepada desa tahun 2017

Peraturan Pemerintah Republik Indonesia Nomor 72 Tahun 2005 tentang Desa

Permana, Cornelius Herdita Aries, Daru Purnomo. (2013). Evaluasi program pemberdayaan masyarakat (suatu analisis dalam perspektif pemberdayaan masyarakat). Salatiga: Universitas Kristen Satya Wacana

Pramanik, Ataul Huq. (2012). Development and democratization from the perspective of islamic world view: the role of civil society versus state in the Arab world. Humanomics, 28(1), 5-25

Ramly, A. R., Wahyuddin., Mursyida, J., \& Mawardati. (2018).Implementasi kebijakan dana desa dalam pengelolaan dan peningkatan potensi desa (studi kasus Kecamatan Kuala Kabupaten Nagan Raya). Prosiding Seminar Nasional USM

Rasila, B.N, M.J. Mudau. (2013). Citizen participation in local government: the importance of effective communication in rural development. International Journal of Community Development, 1(1), 1218

Rencana pembangunan jangka menengah desa (RPJM - Desa) Desa Megaluh Kecamatan Megaluh Kabupaten Jombang Propinsi Jawa Timur Tahun 2014-2019

Ridlwan, Z. (2015). Payung hukum pembentukan BUMDes. Fiat Justisia, 7(3). https://doi.org/10.25041/fiatjustisia.v7no3.396

Salleh, M. Syukri. (2003). Tujuh prinsip pembangunan berteraskan Islam. Kuala Lumpur: Zebra Editions SDN. BHD

Samego, Indria, R. Siti Zuhro, Sri Yanuarti. (1996). Masyarakat, politik dan pembangunan pedesaan. Jakarta: PPW-LIPI

Sen, Amartya. (1999). Development as freedom. Oxford: Oxford University Press. 
Sumardjo. (2010). Penyuluhan menuju pengembangan kapital manusia dan kapital sosial dalam mewujudkan kesehjateraan rakyat. Bandung: Orasi Guru Besar, IPB

Supriadi, E. (2015). Pertanggungjawaban kepala desa dalam pengelolaan keuangan desa berdasarkan undang-undang nomor 6 tahun 2014 tentang desa. Kajian Hukum Dan Keadilan IUS

Susetiawan. (2010). Undang-Undang Desa: Menuju pembangunan desa berkelanjutan. Artikel Yogyakarta.

Undang-Undang RI Nomor 23 Tahun 2014 tentang pemerintah daerah

Undang-Undang RI Nomor 33 Tahun 2014 tentang perimbangan keuangan antara pusat dan pemerintah daerah

Undang-Undang RI Nomor 6 Tahun 2014 dan Peraturan Pemerintah RI Tahun 2016 tentang Desa. 2016. Bandung: Citra Umbara

United Nations Development Programme. (2016). Human development report 2016 human development for everyone. United nations development programme. https://doi.org/eISBN: 978-92-1-0600361

Waheduzzaman. (2010). People's participation for good governance: a study of rural development programs in Bangladesh. Dessertation, Doctor of Philosophy of Victoria University

Yin, K Robert K. (2003). Studi kasus (desain dan metode). Jakarta: PT. Rajagrafindo Persada 